\title{
Adipose tissue metabolism and its role in adaptations to undernutrition in ruminants
}

\author{
Yves Chilliard*, Anne Ferlay, Yannick Faulconnier, Muriel Bonnet, Jacques Rouel and \\ François Bocquier \\ Adipose Tissue and Milk Lipids Team of the Research Unit on Herbivores, INRA - Theix, \\ 63122 St Genès Champanelle, France
}

\begin{abstract}
Changes in the amount and metabolism of adipose tissue (AT) occur in underfed ruminants, and are amplified during lactation, or in fat animals. The fat depot of the tail of some ovine breeds seems to play a particular role in adaptation to undernutrition; this role could be linked to its smaller adipocytes and high sensitivity to the lipolytic effect of catecholamines. Glucocorticoids and growth hormone probably interact to induce teleophoretic changes in the AT responses to adenosine and catecholamines during lactation. Fat mobilization in dry ewes is related both to body fatness and to energy balance. The in vivo $\beta$-adrenergic lipolytic potential is primarily related to energy balance, whereas basal postprandial plasma non-esterified fatty acids (NEFA) are related to body fatness, and preprandial plasma NEFA is the best predictor of the actual body lipid loss. Several mechanisms seem to be aimed at avoiding excessive fat mobilization and/or insuring a return to the body fatness homeostatic set point. As well as providing the underfed animal with fatty acids as oxidative fuels, AT acts as an endocrine gland. The yield of leptin by ruminant AT is positively related to body fatness, decreased by underfeeding, $\beta$-adrenergic stimulation and short day length, and increased by insulin and glucocorticoids. This finding suggests that the leptin chronic (or acute) decrease in lean (or underfed respectively) ruminants is, as in rodents, a signal for endocrine, metabolic and behavioural adaptations aimed at restoring homeostasis.
\end{abstract}

Ruminant undernutrition: Adipose tissue: Lipogenesis: Leptin

The capacity of ruminants to cope with periods of food shortage is the result of a long evolutionary process in natural harsh conditions, and further modified by man's intervention through selecting specialized breeds. When animals are underfed they mobilize their body reserves, which have then to be restored during the more favourable season in order to allow them to enter another cycle of reproduction. This mobilization of body reserves, which occurs even in non-productive animals, is amplified during pregnancy and lactation by the increase in physiological requirements. Distinctions should be made between different timescales: short-term adaptations due to diurnal feeding frequency or day-to-day changes in food availability; medium-term adaptations that appear within a few weeks; long-term adaptations that require animals to progress towards a new equilibrium in a different nutritional and/or physiological context.

Endocrine and metabolic responses to undernutrition are primarily aimed at maintaining, within certain limits, the constancy of the internal environment (homeostasis). Thus, short-, medium- and long-term adaptations in underfed animals result in the orderly mobilization of endogenous substrates (body reserves), sparing glucose and amino acids, plus lowering of metabolic rate and energy expenditure. Whereas homeostatic regulations are directed to the survival of individuals, teleophoretic (or homeorhetic; according to the Greek, 'homeorhesis' (Bauman \& Vernon, 1993) means 'a steady flow', whereas 'teleophoresis' (Chilliard, 1986, 1999) means 'a transport that is oriented towards a goal') regulations ensure the perpetuation of the species through integrated reproductive functions (breeding, pregnancy, lactation and growth). Teleophoretic hormones (produced mainly by the pituitary gland and reproductive organs) act chronically and coordinate changes in the metabolism of body tissues that are necessary to support a new physiological state by re-adjusting the homeostatic set points (Bauman \& Vernon, 1993). However, there can be some situations (especially in underfed animals) where the 
demands for teleophoresis lead to disruptions in homeostasis (e.g. ketosis, fatty liver and impaired reproduction; Chilliard, 1999).

\section{Changes in body fat during undernutrition}

Body fat mobilization varies according to the severity of undernutrition (feeding level and duration) and to initial body fatness. In dry non-pregnant ewes that were moderately fat ( $290 \mathrm{~g}$ lipid/kg body weight $(\mathrm{BW})$ ) and fed at $40 \%$ maintenance requirements for 8 weeks, the total lipid loss was $5.9 \mathrm{~kg}$, i.e. $28 \%$ initial lipids (F Bocquier and Y Chilliard, unpublished results). Ewes differing largely in body lipid $(10.3$ v. $33.8 \mathrm{~kg}$, i.e. 240 v. $430 \mathrm{~g} \mathrm{lipid} / \mathrm{kg} \mathrm{BW})$ and protein $(6.0 v .8 .6 \mathrm{~kg})$ content, and severely underfed for 21 weeks mobilized similar amounts of protein (1.6 v. $1.9 \mathrm{~kg})$, but different amounts of fat $(6.3 v .15 .4 \mathrm{~kg}$; Panaretto, 1964). Furthermore, in ewes that were either underfed or fed near maintenance level, body fat loss was higher in ewes that were initially fatter, despite the fact that feed intake was strictly adjusted to their individual BW (Fig. 1). This finding suggests that the energy requirements on a per $\mathrm{kg} \mathrm{BW}^{0.75}$ basis are higher and/or the efficiency of energy utilization is lower in fat ewes, notwithstanding the fact that these ewes have a lower proportion of BW as lean tissues which are known to have a high $\mathrm{O}_{2}$ consumption per mass unit (Chilliard et al. 1998b). This factor could reflect a feedback mechanism aimed at bringing the ewes back to their previous body fatness set point.

Dry Barbary ewes fed at $20 \%$ maintenance requirements for 24 weeks lost $8.8 \mathrm{~kg}$ adipose tissue (AT), i.e. $85 \%$ of their initial fat depots. In these ewes the supplementary fat depot of the tail $(2-3 \mathrm{~kg}$, i.e. $15-25 \%$ of their total fat depots) has a priority equivalent to the perirenal fat depot, and is continuously mobilized until almost totally emptied

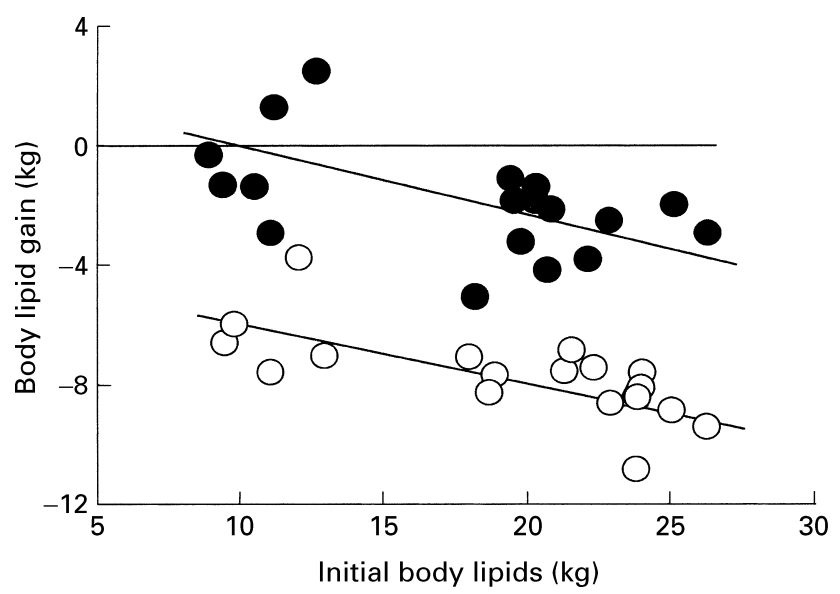

Fig. 1. Change in body lipids in thirty-six ewes that were fed for 12 weeks at either $110 \%(\bullet)$ or $50 \%(\bigcirc)$ initial maintenance energy requirements (MR; estimated as $310 \mathrm{~kJ}$ metabolizable energy $/ \mathrm{kg}$ body weight ${ }^{0 \cdot 75}$ ). Ewes were previously either underfed or overfed in order to achieve different body fatness before the beginning of the experiment. Body lipids were measured, using the ${ }^{2} \mathrm{H}_{2} \mathrm{O}$ method, at the beginning of the experiment and 12 weeks later. At $110 \% \mathrm{MR}$, $y=-0 \cdot 17 x+1 \cdot 4, r 0.52$; at $50 \% \mathrm{MR}, y=-0 \cdot 18 x-3 \cdot 8, r 0 \cdot 69$. (From $\mathrm{F}$ Bocquier, J Rouel and $Y$ Chilliard, unpublished results.) after long-term underfeeding (Atti \& Bocquier, 1999). There is a clear difference of fatness between fat-tailed and thin-tailed types of ewes; at the same empty BW of 50 or $25 \mathrm{~kg}$, the Barbary ewe is fatter (400v. $110 \mathrm{~g} \mathrm{AT} / \mathrm{kg}$ empty BW) than a thin-tailed ewe of the Rasa Aragonesa breed (330 v. $60 \mathrm{~g} \mathrm{AT} / \mathrm{kg}$ empty BW respectively). This difference is due to both tail and subcutaneous fat depots (Teixeira et al. 1989; Atti \& Bocquier, 1999). Their high level of fatness, together with their ability to maintain a moderate rate of fat mobilization from the tail (i.e. at a slower rate than the other subcutaneous AT), may explain the long survival of the Barbary ewe during very severe underfeeding (Le Houérou, 1992).

Body lipid loss during early lactation is highly variable, since the level of undernutrition depends on the milk yield (or the number of lambs being suckled), the appetite of the animals and the level of food supply. A loss of 30-40\% of the initial lipids $(3-6 \mathrm{~kg}$ in ewes and goats, and $20-50 \mathrm{~kg}$ in dairy cows) in 6 weeks is very common, and can rise to $80 \%$ of the body fat in underfed animals (Chilliard, 1987, 1999). Body lipid loss is generally higher in suckling (mean 6.4 (SD 3.4) $\mathrm{kg}$, in four trials) than in milking (mean 1.8 (SD 1.1) kg, in four trials) ewes (Bocquier et al. 2000). The lipid mobilization during lactation is clearly dependent on initial fatness in either thin- (Cowan et al. 1982) or fat-tailed ewes (Atti et al. 1995), and in dairy cows (Chilliard, 1992), when they are severely underfed. When the undernutrition is moderate, however, initial body fatness has only a limited influence on fat mobilization (Cowan et al. 1982). Hence, in contrast to dry ewes (Panaretto, 1964), lactating ewes are able to mobilize a large amount of body lipids without health problems (Cowan et al. 1980). This difference between lactating and dry animals in managing an intense body lipid mobilization is probably related to the large mammary drain of non-esterified fatty acids (NEFA; see p. 130).

\section{Adipose tissue lipogenesis}

Ruminant body lipids can be either synthesized de novo, mainly in AT from acetate and to a lower extent from lactate, or arise from hydrolysis of plasma triacylglycerols (TG) by lipoprotein lipase (LPL). The decrease in the rates of fatty acid (FA) synthesis and LPL activity during fasting, and return to previous or higher values during refeeding, are slower in ruminants than in non-ruminants due to a buffering effect of the rumen (Chilliard et al. 1998b). In adult bovine animals, the lipogenic enzymes in subcutaneous AT are less responsive to underfeeding-refeeding compared with those in perirenal AT; however, LPL activity responds similarly in both AT sites of sheep and cattle (Faulconnier et al. 1999a). These changes are due, at least in part, to pretranslational regulation of key enzymes such as LPL and FA synthase (Bonnet et al. 1998). Among the two major LPL mRNA transcripts, the $3.4 \mathrm{~kb}$ transcript predominates (approximately $60 \%$ ) in sheep AT, whereas the $3.8 \mathrm{~kb}$ predominates in cardiac muscle (approximately $60 \%$ ). These values (assessed by real-time reverse transcription-polymerase chain reaction) were not changed by underfeeding-refeeding, despite large variations in the amounts of LPL total mRNA (Bonnet et al. 1999). 
The decrease in AT lipogenic activities during early lactation (Chilliard, 1987; Vernon, 1998) is probably linked more to the extent of the negative energy balance that occurs at this period than to lactation per se, since lipogenic activities are restored during the declining phase of lactation in dairy cows (McNamara, 1989; Chilliard, 1999). However, it may be that lactation and negative energy balance interact to increase inhibition of AT lipogenesis. The decrease in the activity of acetyl-CoA carboxylase, a key enzyme of FA synthesis, during sheep lactation is due to a fall in the amount of acetyl-CoA carboxylase mRNA as well as several changes in post-transcriptional and posttranslational regulation (Vernon, 1998).

Regulation of the amount and activity of key lipogenic enzymes during mid-term undernutrition is due in part to a decrease in insulin secretion. This homeostatic regulation of the lipogenic pathways is probably exacerbated by shortterm changes in plasma concentrations of insulin and lipogenic substrates, in particular the increase in NEFA, and the decreases in acetate, TG and, less marked, glucose (Chilliard et al. 1998b). The increase in growth hormone (GH) secretion that is generally associated with undernutrition, and in particular with early lactation, is also of importance because this teleophoretic hormone markedly decreases AT response to the lipogenic effect of insulin (Bauman \& Vernon, 1993). The increase in plasma NEFA concentration may inhibit directly the gene expression or activity of lipogenic enzymes, such as ACC, but also induces insulin resistance. The insulin resistance of AT during lactation is specific for lipogenesis (lactate production and protein synthesis are unchanged) and is due to a defect downstream of the insulin receptor, at a late event in the signalling pathway (Vernon, 1998). However, insulin was efficient in decreasing plasma NEFA in early lactating cows (Gagliostro \& Chilliard, 1991), but it is not known if this effect was on FA re-esterification and/or on the lipolytic cascade.

\section{Adipose tissue lipolysis and fat mobilization}

NEFA release from AT is the net result of lipolysis of adipocyte TG by hormone-sensitive lipase, and reesterification in situ of some of the liberated FA. Plasma NEFA concentration increases during fasting until a plateau (about $1 \mathrm{mM}$ ) is reached after $4-8 \mathrm{~d}$. This effect probably results from anti-lipolytic feedback mechanisms to spare body lipids and so prolong survival (Vernon, 1992, 1998), and/or to alleviate toxic effects of high (2 mM) NEFA concentrations (Pethick \& Dunshea, 1993). The return to prefasting concentrations after refeeding is usually very rapid (1-2 d; Chilliard et al. 1998b). However, the kinetics of plasma NEFA differed between Barbary and Lacaune ewes when food intake was kept at a constant low level (according to the initial BW). NEFA concentrations increased sharply in both breeds (Fig. 2). Although the values remained close to the maximum for 13 weeks in Lacaune ewes, they declined steadily in Barbary ewes to $0 \cdot 1-0.2 \mathrm{mM}$ above those for the controls after 12 weeks, i.e. approximately $25-35 \%$ of the initial response. The difference between the two breeds may reflect a better ability of Barbary ewes (Bocquier et al. 2000) to decrease their energy expenditure during undernutrition (Chilliard et al. 1998b).

The increased NEFA mobilization during the period of negative energy balance in early lactation (Chilliard, 1999) and during chronic undernutrition (Dunshea et al. 1988) is due to a decrease in FA re-esterification, together with increased lipolysis (Dunshea et al. 1990). Lipolysis is maintained as lactation progresses, but re-esterification increases (in agreement with in vitro data: McNamara, 1989; Gagliostro \& Chilliard, 1991), providing an important teleophoretic substrate cycle which is energetically expensive, but offering metabolic flexibility to maintain the potential for rapid changes in the flow of FA substrates to other tissues.

\section{Regulation by catecholamines}

The changes in fat mobilization during underfeeding can be linked to changes in glycaemia and insulinaemia, and to changes in the activity of the sympathetic nervous system and the secretion of catecholamines. Indeed, glucose and insulin stimulate FA re-esterification, whereas insulin inhibits lipolysis and catecholamines generally stimulate lipolysis (Vernon, 1992; Chilliard et al. 1998b). Effects of fasting or underfeeding on in vitro basal and/or catecholamine-stimulated lipolysis are inconsistent, although fasting decreased the number of anti-lipolytic adenosine receptors, and increased the affinity of $\beta$-adrenergic receptors (Houseknecht et al. 1995) and the expression of hormone-sensitive lipase gene (Bonnet et al. 1998) in the AT of cattle.

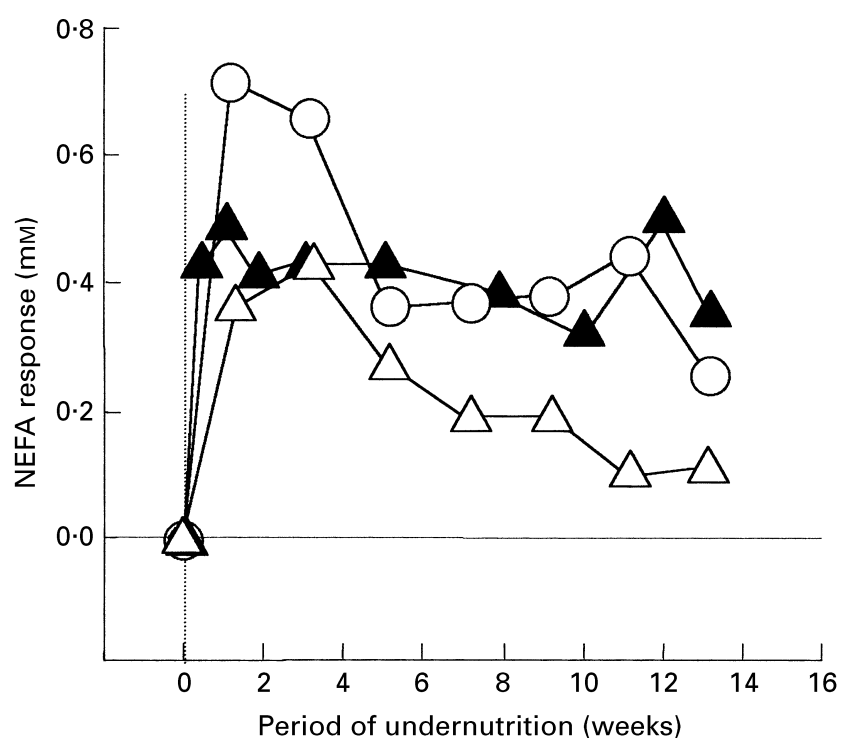

Fig. 2. Plasma non-esterified fatty acids (NEFA) response (treatedcontrol) in Barbary $(O, \triangle ; N$ Atti and $F$ Bocquier, unpublished results) or Lacaune ( $\mathbf{\Delta}$; F Bocquier, J Rouel, A Ferlay and Y Chilliard, unpublished results) ewes subjected to a constant low energy supply $(20(\bigcirc), 40(\triangle)$ or $50(\Delta) \%$ initial maintenance requirements $(M R))$. Mean plasma NEFA in control groups (fed at approximately MR) were $0.24,0.24$ and $0.15 \mathrm{~mm}$ for 20,40 and $50 \%$ MR groups respectively. 
The in vivo plasma NEFA response to a $\beta$-adrenergic challenge (intravenous injection) in dry non-pregnant cows is markedly decreased after consumption of a meal and increased by mid-term underfeeding. However, the effect of the consumption of a smaller meal was not significant in underfed animals, due to either a lower post-feeding insulin secretion or insulin resistance in underfed cows (Chilliard et al. 1998c). The $\beta$-adrenergic response to underfeeding is due in part to the $\beta_{2}$-adrenergic response, whereas there is no lipolytic effect of a $\beta_{1}$-agonist intravenously infused in cattle (Ferlay \& Chilliard, 1999). In dry non-pregnant underfed ewes the in situ glycerol response to adrenaline infusion into AT, using microdialysis, was mimicked by isoproterenol (ISO; $\beta$-agonist), suggesting a low contribution of the anti-lipolytic $\alpha_{2}$ adrenergic pathway. The $\beta$-adrenergic response was partly reproduced by a selective $\beta_{2}$-agonist, but not by a selective $\beta_{3}$-agonist (Ferlay et al. 1998).

The lipolytic sensitivity of different AT to ISO or adrenaline addition in vitro was ten times greater in the fat-tailed Karakul breed than in thin-tailed Outaouais ewes (Gilson et al. 1996). This factor could allow the control of fat mobilization by small changes in the secretion of catecholamines, and possibly facilitate the adaptation to seasonal underfeeding in fat-tail ewes.

Lactation increases both maximum response and sensitivity to catecholamines, with increases in the number of $\beta$-adrenergic receptors and in adenylate cyclase activity (Vernon et al. 1995a). However, the response to the antilipolytic factor, adenosine, is also increased during lactation (Vernon, 1998). Furthermore, the in vivo response of plasma NEFA to a $\beta$-adrenergic challenge is lower in lactating animals than in dry animals at similar energy balance, because the high rate of NEFA use by the mammary gland allows a greater expression of the AT lipolytic potential without a major increase in plasma NEFA concentrations (Pethick \& Dunshea, 1993; Chilliard et al. 1998c).

\section{Regulation by growth hormone}

Exogenous GH increases the lipolytic effect of adrenaline challenge in lactating cows (Bauman \& Vernon, 1993). It is not clear whether $\mathrm{GH}$ acts directly or through a decrease in energy balance (due to increased milk yield), because GH administration does not change the NEFA response to adrenaline or ISO challenge in dry non-pregnant, underfed or overfed, cows (Ferlay et al. 1996). Exogenous GH in lactating cows does not change in vitro AT $\beta$-adrenergic response but decreases the anti-lipolytic effect of adenosine, downstream of its receptor, by a mechanism different from that of fasting (Houseknecht \& Bauman, 1997). One hypothesis is that the $\beta$-adrenergic lipolysis is less responsive to GH in dry cows because they lack other teleophoretic factors (e.g. glucocorticoids, as suggested by Vernon (1998)) that are known to increase both $\beta$-adrenergic lipolytic and adenosine anti-lipolytic effects, and that could allow indirect $\mathrm{GH}$ effects via the adenosine signalling pathway in lactating cows.

A permissive and dual action of $\mathrm{GH}$ on AT metabolism is suggested by the fact that in GH-treated dairy cows there is a change from a higher mobilization towards a greater deposition of body lipids when the GH treatment is prolonged for several months (Chilliard, 1999), i.e. AT metabolism is linked to the temporal fluctuations in energy balance, with a recovery period allowed by respective changes in milk yield and energy intake. There are, however, only limited metabolic data from long-term studies. In dairy goats AT lipogenesis and glucose utilization were still decreased by $\mathrm{GH}$ after 22 weeks of treatment (Vernon et al. 1995b).

\section{Relationship with adipose cell size or body fatness}

Rates of in vitro ISO-stimulated (but not basal) lipolysis per adipocyte are higher in AT explants of fat ewes with larger adipocytes (Vernon et al. 1995a). It is noteworthy that in the Karakul ewe the fat-tail depot has smaller adipocytes and is less responsive in vitro to ISO or adrenaline than other fat depots (Gilson et al. 1996). This factor may be involved in the moderate rate of mobilization (Atti \& Bocquier, 1999) of this particular fat depot.

Response to an ISO challenge is primarily related to the amount of body lipids in well-fed lactating ewes, but to energy balance when animals are underfed (Bocquier et al. $1998 b)$. The influence of energy balance on the correlation between in vivo $\beta$-adrenergic lipolysis and body fatness in ruminants was recently confirmed in both dry cows (A Ferlay and Y Chilliard, unpublished results) and dry ewes (Fig. 3). Within the thirty-six ewes fed at either 0.5 or $1 \cdot 1$ times maintenance requirements (Fig. 3), 54 and $10 \%$ of the variance in basal (postprandial) plasma NEFA concentrations were explained by body fatness and feeding level respectively. In contrast, 22 and $46 \%$ of the variance in preprandial plasma NEFA concentrations, and 2 and $50 \%$ of the variance in the response of plasma NEFA to an ISO challenge were explained by body fatness and feeding level respectively. These results suggest that the NEFA response to an ISO challenge reflects the lipolytic potential of the AT of underfed animals. This lipolytic potential would be regulated primarily according to physiological needs and secondarily by the amount of lipid stores, with the probable exception of very lean animals which do not have enough AT to respond to physiological needs (Chilliard, 1992). However, the basal (postprandial) plasma NEFA concentration is mainly linked to initial body fatness (Fig. 3). On the other hand, the preprandial plasma NEFA concentration, which was related to both feeding level and body fatness, was the best predictor $(r 0 \cdot 68, n 36)$ of the subsequent rate of body lipid loss (Fig. 1).

There was no desensitization to an ISO challenge in dry non-pregnant cows (Ferlay \& Chilliard, 1999) or ewes ( $\mathrm{F}$ Bocquier, A Ferlay and Y Chilliard, unpublished results), after 4 or 12 weeks of underfeeding at 60 or $50 \% \mathrm{MR}$ respectively. This result conforms to the notion that the $\beta$-adrenergic lipolytic potential is increased by underfeeding to a level above that required to cover the physiological needs.

These observations can be compared with results obtained either in vivo or in vitro with lactating cows. Basal and ISO-stimulated plasma NEFA concentrations were highly correlated with the energy balance of the animals, 

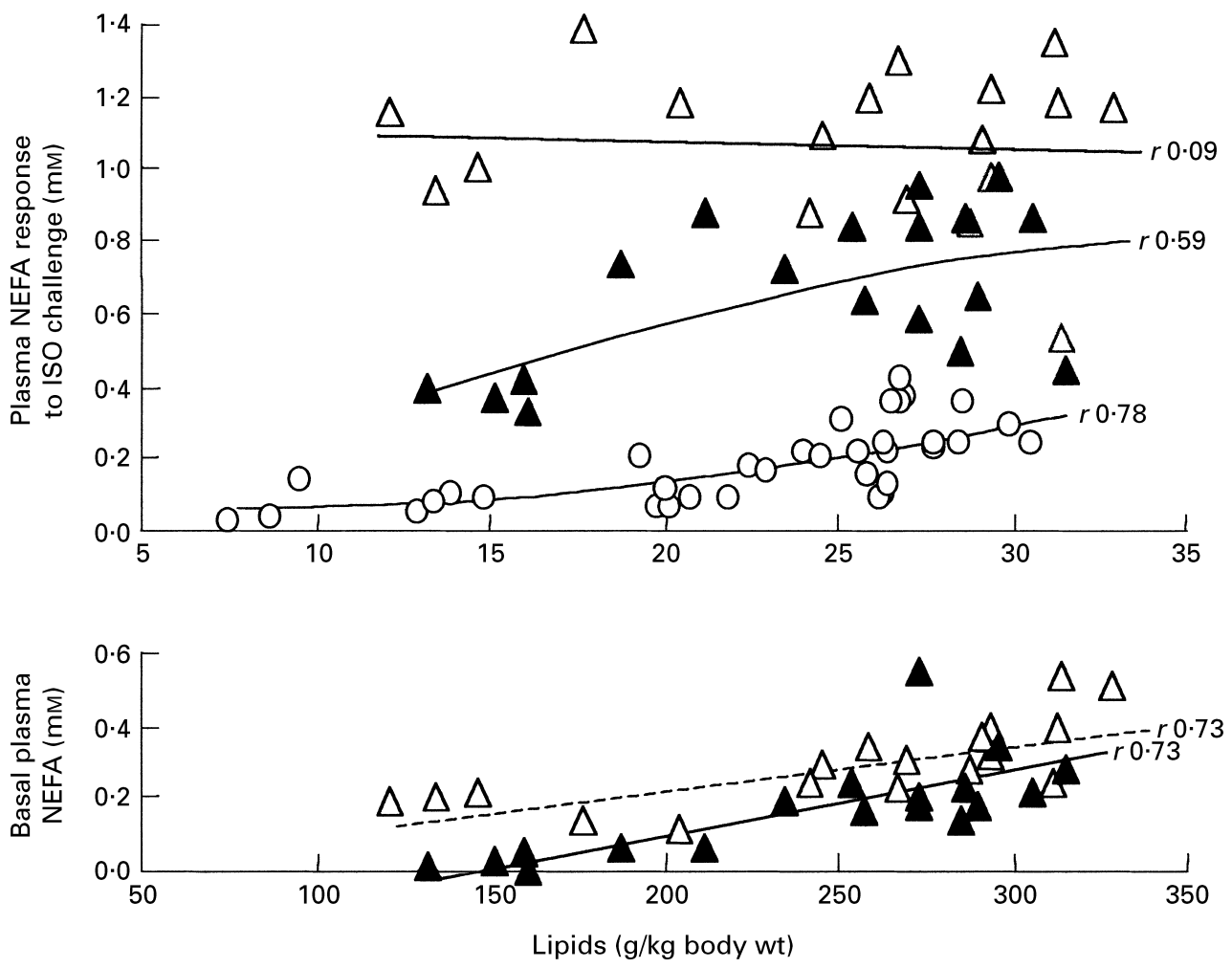

Fig. 3. Relationship between body fatness and either basal plasma (postprandial) non-esterified fatty acids (NEFA) or the response to an isoproterenol (ISO) challenge. Ewes were fed at $0.5(\triangle ; n 18)$ or $1.1(\boldsymbol{\Lambda} ; n$ 18) times maintenance requirements $(\mathrm{MR})$ for 12 weeks, or refed $(O$; $n$ 36) at $2 \cdot 3$ times MR for $5 \mathrm{~d}$. (From F Bocquier, J Rouel, A Ferlay and Y Chilliard, unpublished results.)

while the correlation with adipocyte size was lower (which reflects body lipid content); however, the opposite was true for in vitro basal and ISO-stimulated NEFA release by AT explants incubated for $90 \mathrm{~min}$ immediately after biopsy (Gagliostro \& Chilliard, 1991). This finding suggests that the short-term in vitro lipolytic activity and response to ISO are more related to AT cellularity than to the physiological conditions operating in vivo before AT sampling, and could explain the inconsistent responses of in vitro lipolysis to in vivo nutritional or physiological changes (Bauman \& Vernon, 1993). The higher rates of lipolysis both in vitro and in vivo for animals in positive energy balance when AT has larger fat cells may be due to the higher production by these cells of autocrine or paracrine factors, such as leptin (Chilliard et al. 1998a) or tumour necrosis factor $\alpha$ (RG Vernon, personal communication), that limit cell enlargement.

It can be concluded from these observations that fat mobilization is physiologically related both to body fatness and to day-to-day energy balance. A drop in energy balance is primarily related to an increase in the in vivo $\beta$-adrenergic lipolytic potential, thus ensuring fuel availability for survival. However, the actual rate of fat mobilization results from a fine modulation of this lipolytic potential by known or unknown factors, aimed at ensuring a return to the body fatness set point and/or avoiding excessive mobilization. These factors could also play a role in the lower energetic efficiency of fat ewes (Fig. 1), and may be viewed as the price that fat animals have to pay for a longer survival ability.

\section{Role of adipose tissue in adaptation to undernutrition}

\section{Intermediary metabolism}

During fasting in dry animals fat mobilization can account, in theory, for total energy requirements, and thus spare glucose and amino acids as oxidative fuels (Pethick \& Dunshea, 1993). During early lactation the NEFA released by AT contribute directly and substantially to milk fat secretion and to oxidative energy metabolism in different tissues, and thus spare glucose and amino acids for the mammary gland (Vernon, 1998; Chilliard, 1999).

When ruminants are in positive energy balance ketone bodies arise mainly from metabolism of butyrate by the rumen wall. During undernutrition whole-body ketogenesis increases through partial oxidation of NEFA and TG, with the main site of synthesis being the liver. The ability of non-AT tissues to utilize NEFA and ketone bodies, and of liver to synthesize TG and to secrete lipoproteins, avoids attainment of toxic concentrations of plasma NEFA and determines whether clinical ketosis and/or liver steatosis will be established. The differences in hepatic metabolism of NEFA between ruminants and rats, mainly orientated towards ketone body production in ruminants or lipoprotein synthesis in rats, may explain the fact that undernutrition markedly decreases plasma TG as well as heart and skeletal muscle LPL activities and mRNA in ruminants but not in rodents (Bonnet et al. 1999; Faulconnier et al. 1999a,b).

The duration of survival of the animal then depends on the level of body reserves before undernutrition, and on the kinetics and physiological limits of fat and protein 
mobilization. Few data are available in ruminants, but extensive studies in human subjects, rats and birds (Cherel et al. 1992) have shown that in lean animals the duration of fasting is limited by lipid exhaustion, and hence by energy availability for gluconeogenesis from mobilized amino acids. However, during underfeeding fat ewes died before less than $25-30 \%$ of their body protein and $50 \%$ of their body lipids were mobilized (Panaretto, 1964). The animals did indeed stop eating, probably because of metabolic disturbances caused by excessive lipid mobilization. Thus, body fat cannot prevent body protein loss, and too much fat may even inhibit behavioural adaptations that anticipate lethal depletion of body protein or metabolic disturbances.

\section{Leptin and neuroendocrine regulations}

Apart from a role as an energy store, AT acts as an endocrine gland that secretes several autocrine, paracrine and endocrine factors. Leptin is secreted by adipocytes and has a role as a chronically-acting lipostatic factor that regulates appetite, energy expenditure and reproduction, as demonstrated in rodents (Friedman \& Halaas, 1998). It was also proposed that the decrease in plasma leptin concentration during starvation would be central to the neuroendocrine adaptations that ensure animal survival, because exogenous leptin administration substantially blunts the usual responses in thyroxine, corticosterone and gonadal activity to starvation in mice (Ahima et al. 1996). Thus, the low leptin concentration during undernutrition could yield an acute signal for increased feeding, higher glucocorticoid secretion, lower thyroid activity, lower energy expenditure and protein synthesis, and decreased reproductive activity (Friedman \& Halaas, 1998; Heiman et al. 1999).

Such a putative role for leptin in ruminants is in keeping with our results showing that sheep AT leptin mRNA is decreased by underfeeding, as is plasma immunoreactive leptin in cattle and sheep (Bocquier et al. 1998a; Fig. 4). Furthermore, plasma leptin is decreased by a $\beta$-agonist infusion in cattle, and positively correlated with body

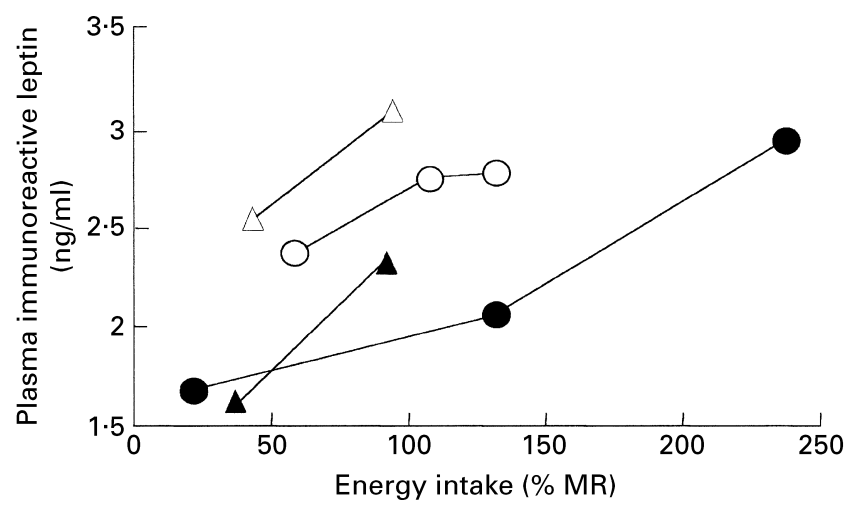

Fig. 4. Effect of the level of energy intake on plasma immunoreactive leptin in cattle $(\bigcirc$, eighteen cows; $\bullet$, five cows) and sheep $(\triangle, \boldsymbol{\Delta}$, eight ewes). All animals were dry and non-pregnant, and received successively each feeding level in the trials. MR, maintenance requirement. (Adapted from Chilliard et al. 1998a.) fatness in cattle and sheep (Chilliard et al. 1998a). This correlation could be related to the reduced appetite and lower energetic efficiency of fat animals. In vitro, insulin and glucocorticoids stimulate leptin yield by sheep AT explants (Y Faulconnier, C Delavaud and Y Chilliard, unpublished results) and leptin mRNA in cattle AT explants, whereas GH blocks these effects (Houseknecht et al. 1998). From these results a decrease in ruminant plasma leptin could be anticipated during early lactation when plasma insulin is low, plasma GH and NEFA are high, and AT is insulin resistant and more sensitive to catecholamines. Furthermore, lactation was shown to suppress the nocturnal rise in plasma leptin in rats, which could be a factor promoting hyperphagia during lactation (Pickavance et al. 1998).

Another aspect of adaptation to undernutrition is the interaction between reproduction and seasonal factors, including fluctuations of day length, food availability and the level of body reserves. This interaction may prevent emaciated animals from risks linked with the high nutritional demand of subsequent pregnancy and lactation, which may impair the survival of both the mother and the offspring (Ortavant et al. 1988). We have observed that luteinizing hormone pulsatility is more sensitive to undernutrition when ewes contain less than 150-200 g fat $/ \mathrm{kg} \mathrm{BW}$ (F Bocquier, A Caraty, P Chemineau and Y Chilliard; unpublished results).

We investigated the effect of day length on AT metabolism in ovariectomized ewes that were pair-fed. Short days decrease both AT leptin expression and plasma leptin, increase plasma NEFA and decrease the activities of lipogenic enzymes (especially LPL and malic enzyme) in AT (Bocquier et al. 1998a; Chilliard \& Bocquier, 2000). The lipolysis-lipogenesis results suggest that day length could change the homeostatic set points in AT, thus anticipating body fat mobilization during winter undernutrition, and restoration when food availability is high during spring or summer. On the other hand, the leptin data suggest that long days could induce a leptin resistance of the brain regions that regulate appetite and reproduction, because long days usually stimulate food intake and inhibit reproduction in sheep. Such a leptin resistance would also favour the rebuilding of body stores before the future breeding season that will be induced by decreasing day length. Complex temporal interactions between hypothalamic and pituitary hormones, insulin, glucocorticoids, catecholamines and leptin are probably involved in these regulations (Chilliard \& Bocquier, 2000). These observations suggest that leptin is acting as a homeostatic as well as a teleophoretic hormone.

\section{Conclusion}

AT metabolism is highly reactive and finely regulated, to act both as an energy-storage tissue and as an endocrine gland. It is exposed to short-term homeostatic regulation linked to nutritional status and changes in environment, to long-term teleophoretic regulation linked to physiological status, and also to anticipatory homeostatic or teleophoretic regulation, e.g. by photoperiod. Furthermore, long-term homeostasis is ensured by feedback mechanisms that favour the return to 
the body lipid set point after any change in body fat deposition or mobilization.

\section{Acknowledgements}

We are grateful to Marianne Borel and Pascale Béraud for assistance during the preparation of the manuscript, and to Sue Crawford for help with the English.

\section{References}

Ahima RS, Prabakaran D, Mantzoros C, Qu D, Lowell B, Maratos-Flier E \& Flier JS (1996) Role of leptin in the neuroendocrine response to fasting. Nature 382, 250-252.

Atti N \& Bocquier F (1999) Adaptation des brebis Barbarine à l'alternance de sous-nutrition-réalimentation: effets sur les tissus adipeux (Adaptive capacity of Barbary ewes to underfeeding and refeeding periods: effects on adipose tissues). Annales de Zootechnie 48, 189-198.

Atti N, Nefzaoui A \& Bocquier F (1995) Influence de l'état corporel à la mise bas sur les performances, le bilan énergétique de l'évolution des métabolites sanguins de la brebis Barbarine (Effect of body fatness at lambing on performances, energy balance and blood metabolites in the Barbary ewe). Options Méditerranéennes Série A: Séminaires Méditerranéens no. 27, pp. 25-33. Zaragoza, Spain: Centre International des Haut Etudes Agronomiques Méditerranéenes.

Bauman DE \& Vernon RG (1993) Effects of exogenous bovine somatotropin on lactation. Annual Review of Nutrition 13, 437-461.

Bocquier F, Atti N, Purroy A \& Chilliard Y (2000) The role of body reserves in the metabolic adaptation of different breeds of sheep to food shortage. In Livestock Production and Climatic Uncertainty in the Mediterranean. European Association of Animal Production Publication no. 94 [F Guessous, editor]. Amsterdam: Wageningen Pers (In the Press).

Bocquier F, Bonnet M, Faulconnier Y, Guerre-Millo M, Martin P \& Chilliard Y (1998a) Effects of photoperiod and feeding level on adipose tissue metabolic activity and leptin synthesis in the sheep. Reproduction Nutrition Development 38, 489-498.

Bocquier F, Ferlay A \& Chilliard Y (1998b) Effects of body lipids and energy balance on the response of plasma non-esterified fatty acids to a $\beta$-adrenergic challenge in the lactating dairy ewe. In Energy Metabolism of Farm Animals, pp. 167-173 [K McCracken, EF Unsworth and ARG Wylie, editors]. Wallingford, Oxon: CAB International.

Bonnet M, Faulconnier Y, Fléchet J, Hocquette JF, Leroux C, Langin D, Martin P \& Chilliard Y (1998) Messenger RNAs encoding lipoprotein lipase, fatty acid synthase and hormonesensitive lipase in the adipose tissue of underfed-refed ewes and cows. Reproduction Nutrition Development 38, 297-307.

Bonnet M, Faulconnier Y, Leroux C, Bocquier F, Martin P \& Chilliard Y (1999) Effect of refeeding on two mRNAs species of lipoprotein lipase in adipose and cardiac muscle of sheep. Proceedings of the Nutrition Society 58, 108A.

Cherel Y, Robin JP, Heitz A, Calgari C \& Le Maho Y (1992) Relationships between lipid availability and protein utilization during prolonged fasting. Journal of Comparative Physiology 162B, 305-313

Chilliard Y (1986) Variations quantitatives et métabolisme des lipides dans les tissus adipeux et le foie au cours du cycle gestation-lactation. 1 - Chez la ratte (Body composition and lipid metabolism in adipose tissues and liver during pregnancy and lactation. 1 - In the rat). Reproduction Nutrition Development 26, $1057-1103$.
Chilliard Y (1987) Variations quantitatives et métabolisme des lipides dans les tissus adipeux et de foie au cours du cycle gestation-lactation. 2 - Chez la brebis et la vache (Body composition and lipid metabolism in adipose tissues and liver during pregnancy and lactation. 2 - In the ewe and the cow). Reproduction Nutrition Development 27, 327-398.

Chilliard Y (1992) Physiological constraints to milk production: factors which determine nutrient partitioning, lactation persistency and mobilization of body reserves. World Review of Animal Production 27, 19-26.

Chilliard Y (1999) Metabolic adaptations and nutrient partitioning in the lactating animal. In Biology of Lactation, pp. 503-552 [J Martinet, LM Houdebine and HH Head, editors]. Paris: INRA Ed.

Chilliard Y \& Bocquier F (2000) Direct effects of photoperiod on lipid metabolism, leptin synthesis and milk secretion in adult sheep. Proceedings of the IXth International Symposium on Ruminant Physiology (In the Press).

Chilliard Y, Bocquier F, Delavaud C, Guerre-Millo M, Bonnet M, Martin P, Faulconnier Y \& Ferlay A (1998a) Leptin in ruminants: effects of species, breed, adiposity, photoperiod, beta-agonists and nutritional status. Proceedings of the Cornell Nutrition Conference for Feed Manufacturers, pp. 65-74. Ithaca, NY: Cornell University.

Chilliard Y, Bocquier F \& Doreau M (1998b) Digestive and metabolic adaptations of ruminants to undernutrition, and consequences on reproduction. Reproduction Nutrition Development 38, 131-152.

Chilliard Y, Ferlay A, Despres L \& Bocquier F (1998c) Plasma non esterified fatty acid response to a beta-adrenergic challenge before or after feeding in energy underfed or overfed, dry or lactating cows. Animal Science 67, 213-223.

Cowan RT, Robinson JJ \& McDonald I (1982) A note on the effects of body fatness and level of food intake on rate of fat loss in lactating ewes. Animal Production 34, 355-357.

Cowan RT, Robinson JJ, McDonald I \& Smart R (1980) Effects of body fatness at lambing and diet in lactation on body tissue loss, feed intake and milk yield of ewes in early lactation. Journal of Agricultural Science, Cambridge 95, 497-514.

Dunshea FR, Bell AW \& Trigg TE (1988) Relations between plasma non-esterified fatty acid metabolism and body tissue mobilization during chronic undernutrition in goats. British Journal of Nutrition 60, 633-644.

Dunshea FR, Bell AW \& Trigg TE (1990) Non-esterified fatty acid and glycerol kinetics and fatty acid re-esterification in goats during early lactation. British Journal of Nutrition 64, 133-145.

Faulconnier Y, Bonnet M, Bocquier F, Leroux C, Hocquette JF, Martin P \& Chilliard Y (1999a) Effet du niveau alimentaire et de la photopériode sur l'expression des gènes contrôlant le métabolisme lipidique tissulaire chez le ruminant (Effect of feeding level and photoperiod on the expression of genes encoding enzymes of tissue lipid metabolism in the ruminant). INRA Productions Animales 12, 287-300.

Faulconnier Y, Bonnet M, Fléchet J, Bocquier F \& Chilliard Y (1999b) Nutritional regulation of lipoprotein lipase in bovine adipose tissues and muscles. Proceedings of the Nutrition Society 58, $109 \mathrm{~A}$.

Ferlay A, Charret C, Galitzky J, Berlan M \& Chilliard Y (1998) Effects of the infusion of $\beta-, \beta 2$ - or $\beta 3$ - adrenergic agonists or epinephrine on in situ lipolysis in ewe subcutaneous adipose tissue. Reproduction Nutrition Development 38, 196-197.

Ferlay A \& Chilliard Y (1999) Effects of the infusion of non selective $\beta$-, and selective $\beta 1$ - or $\beta 2$-adrenergic agonists, on body fat mobilisation in underfed or overfed non-pregnant heifers. Reproduction Nutrition Development 39, 409-421.

Ferlay A, Chilliard Y, Sala AM, Durier C \& Bocquier F (1996) Somatotropin treatment does not effect non-esterified fatty acid 
response to adrenergic injections in underfed or overfed nonlactating cows. Journal of Nutrition 126, 945-954.

Friedman JM \& Halaas JL (1998) Leptin and the regulation of body weight in mammals. Nature 395, 763-770.

Gagliostro G \& Chilliard Y (1991) Duodenal rapeseed oil infusion in early and midlactation cows. 4 . In vivo and in vitro adipose tissue lipolytic responses. Journal of Dairy Science 74, $1830-1843$

Gilson TL, Kennedy AD \& Rampersand T (1996) Effects of breed and adipose depot location on responsiveness and sensitivity to adrenergic stimulation in ovine adipose tissue. Comparative Biochemistry and Physiology 115C, 19-26.

Heiman ML, Sloop KW, Chen Y \& Caro JF (1999) Extension of neuroendocrine axes to include leptin. Journal of Animal Science 77, Suppl. 3, 33-42.

Houseknecht KL \& Bauman DE (1997) Regulation of lipolysis by somatotropin: functional alteration of adrenergic and adenosine signaling in bovine adipose tissue. Journal of Endocrinology 152, 465-475.

Houseknecht KL, Bauman DE, Carey GB \& Mersmann HJ (1995) Effect of bovine somatotropin and food deprivation on betaadrenergic and $A_{1}$ adenosine receptor binding in adipose tissue of lactating cows. Domestic Animal Endocrinology 12, 325-336.

Houseknecht KL, Portocarrero CP, Ji S, Lemenager RP \& Spurlock ME (1998) Growth hormone regulation of leptin gene expression in bovine adipose tissue: in vitro and in vivo studies. International Journal of Obesity 22, Suppl. 3, S166 Abstr.

Le Houérou HN (1992) Recherches expérimentales sur la tolérance du mouton barbarin à l'inanition et la restriction alimentaire (Experimental research on the adaptation of Barbary ewes to starvation and underfeeding). In L'Aridité: Contrainte au Développement (Aridity: A Constraint to Development), pp. 369-385 [E Le Floc'h, M Grouzis, A Cornet and JC Bille, editors]. Bondy, France: ORSTOM éditions.
McNamara (1989) Regulation of bovine adipose tissue metabolism during lactation. 5. Relationships of lipid synthesis and lipolysis with energy intake and utilization. Journal of Dairy Science 72, 407-418.

Ortavant R, Bocquier F, Pelletier JP, Ravault JP, Thimonier J \& Volland-Nail P (1988) Seasonality of reproduction in sheep and its control by photoperiod. Australian Journal of Biology Science 41, 69-85.

Panaretto BA (1964) Body composition in vivo. VI. The composition of ewes during a prolonged undernutrition. Australian Journal of Agricultural Research 15, 771-787.

Pethick DW \& Dunshea FR (1993) Fat metabolism and turnover. In Quantitative Aspects of Ruminant Digestion and Metabolism, pp. 291-311 [JM Forbes and J France, editors]. Wallingford, Oxon: CAB International.

Pickavance L, Tadayyon M, Williams G \& Vernon RG (1998) Lactation suppresses diurnal rhythm of serum leptin. Biochemical and Biophysical Research Communications 248, 196-199.

Teixeira A, Delfa R \& Colomer-Rocher F (1989) Relationships between fat depots and body condition score or tail fatness in the Rasa Aragonesa breed. Animal Production 49, 275-280.

Vernon RG (1992) Effects of diet on lipolysis and its regulation. Proceedings of the Nutrition Society 51, 397-408.

Vernon RG (1998) Homeorhesis. In Yearbook 1998, pp. 64-73 [E Taylor, editor]. Ayr, Scotland: Hannah Research Institute.

Vernon RG, Doris R, Finley E, Houslay MD, Kilgour E \& Linday-Watt S (1995a) Effects of lactation on the signal transduction systems regulating lipolysis in sheep subcutaneous and omental adipose tissue. Biochemical Journal 308, 291-296.

Vernon RG, Faulkner A, Finley E, Watt PW \& Zammit VA (1995b) Effects of prolonged treatment of lactating goats with bovine somatotropin on aspects of adipose tissue and liver metabolism. Journal of Dairy Research 62, 237-248. 